The introduction of sickness insurance in Spain in the first decades of the Franco dictatorship (1939-1962)

\author{
Margarita Vilar Rodríguez \\ Jerònia Pons Pons
}

\title{
Summary
}

Using new statistical data on financing, coverage and economic and health care provisions, this article analyses how sickness insurance was introduced, managed and extended in Spain, under the Franco dictatorship, between 1939 and 1962. This article highlights how the dictatorship accelerated its implementation for political motives and this resulted in a failure of the system due to the lack of public financing and the high pharmaceutical, medical and infrastructure costs.

Key Words: Health; sickness insurance; welfare state; Spain

\section{Contributors note:}

Jerònia Pons Pons is senior lecturer in Economic History at the University of Seville and Margarita Vilar Rodríguez is lecturer in Economic History at the University of Corunna. They have published various articles on sickness insurance in Spain in journals such as the International Review of Social History and Labor History (forthcoming). They have also participated in the collective work on social insurances in Spain entitled Los orígenes del Estado del Bienestar en España, 1900-1945: Ios seguros de accidentes, vejez, desempleo y enfermedad, (University of Zaragoza, 2010). 
In most countries in Europe, the establishment of the first state-sponsored social insurances in the late nineteenth century had two basic precedents: on the one hand, professional insurances that had already been developed on the initiative of employers or workers and, on the other hand, voluntary associations among workers through friendly societies or trade union organisations. ${ }^{1}$ These formulas emerged as a response to the lack of protection afforded to the poorer sections of the population in the nascent industrial society. In some countries (e.g. Great Britain before 1945; Italy, and Ireland), friendly societies ended up being integrated into the public social protection system, still preserving their private character in some cases, while in other countries (e.g. Germany, Belgium, Netherlands, and Spain) they remained outside the state system of coverage. ${ }^{2}$ At the beginning of the twentieth century, a limited group of private insurance companies was added to this panorama, but they had scant capital and provided limited coverage, basically in urban areas.

\footnotetext{
${ }^{1}$ Friendly societies are characterised by being non-profit making voluntary associations in which the insured, who are at the same time insurers, act as administrators and receive aid from common funds in the situations of risk established in their statutes. In most cases, these societies cover the risk of sickness. In France they were called 'Mutualités', in Germany 'Hilfskassen' and in Spain 'Sociedades de Socorro Mutuo'.

${ }^{2}$ The classification by groups of countries has been obtained from Marcel Van der Linden, ed, Social Security Mutualism. The Comparative History of Mutual Benefit Societies (Bern: Peter Lang AG, 1996), 37 and Francisco J. Maldonado, Las Mutualidades de previsión como entidades aseguradoras (Granada: Comares, 2001). More information on the origin, development and role of worker solidarity in social coverage in David T. Beito, From Mutual Aid to the Welfare State: Fraternal Societies and Social Services, 1890-1967 (Chapel Hill: University of North Carolina Press, 2000); Brian J. Glenn, 'Understanding Mutual Benefit Societies, 1860-1960', Journal of Health Politics, Policy and Law, 2001, $26,638-51$.
} 
In general, during these early stages, the coverage of social risks came from four basic sectors with different weight according to the country: the state, the market, the traditional family network - less robust in urban areas - and solidarity among workers. The scenario depicted above represents what Bernard Harris and Paul Bridgen have termed the 'mixed economy of welfare'. ${ }^{3}$ These authors explain that the distribution of responsibilities in matters of social coverage between the state, the market, the family and the civil society was gradually being established in each country with different results. Martin Lengwiler adds that the final result would depend on the relative strength of these agents in the historical context of each country. ${ }^{4}$ As regards health coverage in the United States, John Murray has shown that this led to a predominance of the market of private insurers and a secondary role for the state. ${ }^{5}$ Meanwhile, in Europe, some countries opted for a public health care system and others for mixed systems where the state collaborated with mutuals in order to offer medical health care services. ${ }^{6}$

\footnotetext{
${ }^{3}$ Bernard Harris and Paul Bridgen, eds, Charity and Mutual Aid in Europe and North America since 1800 (Nueva York: Routledge, 2007).

${ }^{4}$ Martin Lengwiler, 'Competing Appeals: The Rise of Mixed Welfare Economies in Europe, 1850-1945' in Gregory Anderson, Christian Thomann and J. Matthias Graf von der Schulenburg, ed., The Appeal of Insurance (Toronto: University of Toronto Press), 173-200.

${ }^{5}$ John E. Murray, Origins of American Health Insurance. A History of Industrial Sickness Funds (New Haven \& London: Yale University Press, 2007).

${ }^{6}$ For more on these aspects, see works such as Bernard Harris, The Origins of the British Welfare State: Society, State and Social Welfare in England and Wales 1800-1945 (Basingstoke: Palgrave Macmillan, 2004); K. P. Companje, R. H. M. Hendriks, K. F. E. Veraghtert and B. E. M. Widdershoven, Two Centuries of Solidarity. German, Belgian and Dutch social health insurance 1770-2008 (Amsterdam: Aksant, 2009).
} 
The pioneering German model of compulsory social insurances served as a reference and topic of discussion for other industrialised countries. However, far from imitating the German precedent, each country progressively established its own system of social coverage, reflecting its own characteristics. In this way, the development of social insurances was very different from country to country, both with respect to the number of risks covered and their management, and the real impact in terms coverage and provisions. $^{7}$ In general terms, an analysis of the historiography of this topic enables us to determine two fundamental differences between social insurance models established prior to the Second World War: a) systems based on the insurance principle versus systems based on the welfare principle; b) compulsory insurance versus voluntary insurance. With regard to the latter, a process of convergence took place after the Second World War, as compulsory insurances were established in almost all European countries.

The factors that explain the different rates of progress in social insurance are very complex. Most authors recognise that the paucity of data on the development of social insurances in many countries before the Second World War hinders a comprehensive quantitative comparison. Consequently, several authors who have attempted to do so have used the dates of passage of the first social insurance laws

\footnotetext{
${ }^{7}$ These differences can be seen in works that attempt to make an international comparison of the different models. These include: Margaret S. Gordon, Social Security Policies in Industrial Countries: a comparative analysis (Cambridge: Cambridge University Press, 1988); Douglas E. Ashford, La Aparición de los Estados de Bienestar (Madrid: Ministerio de Trabajo y Seguridad Social, 1989); Gerhard A. Ritter, El Estado Social, su origen y desarrollo en una comparación internacional (Madrid: Centro de Publicaciones Ministerio de Trabajo y Seguridad Social, 1991); Peter A. Köhler and Hans F. Zacher, eds, The Evolution of Social Insurance, 1881-1981. Studies of Germany, France, Great Britain, Austria and Switzerland (New York: St. Martin's Press, 1982).
} 
as a proxy variable of the development of social insurances. ${ }^{8}$ Other authors who have tried to use variables that are more representative of the real development of these insurances, utilising their coverage rate or the volume of public expenditure, have had to limit themselves to small samples of countries or to studying the particular cases of individual countries. $^{9}$

In general, from a chronological point of view, two basic stages can be distinguished in the process of international diffusion of social insurances according to the historiography. Until the First World War, insurances spread very slowly and, in the majority of cases, under systems of subsidised voluntary pensions known as 'subsidised freedom'. In this first stage, only France, Denmark and the United Kingdom managed to cover the four fundamental risks (industrial accidents, pensions, sickness and unemployment), albeit with limited coverage. Nevertheless, during the interwar period an accelerated development of social insurances took place, above all in Western European countries and some European colonies. The

\footnotetext{
${ }^{8}$ See, for example, Ritter, El Estado Social; Kohler and Zacher, The Evolution of Social Insurance and Chikako Usui, 'Welfare State Development in a World System context: Event History Analysis of First Social Insurance Legislation among 60 countries, 1880-1960', in Thomas Janoski and Alexander M. Hicks, eds, The Comparative Political Economy of the Welfare State (Cambridge: Cambridge University Press, 1994), 254-77.

${ }^{9}$ For an example of the former, see Peter H. Lindert, Growing Public: Social Spending and Economic Growth since the Eighteenth Century (Cambridge: Cambridge University Press, 2004), and for particular case studies, see Paul V. Dutton, Origins of the French Welfare State. The struggle for social reform in France 1914-1947 (Cambridge: Cambridge University Press Dutton, 2002); Derek Fraser, The Evolution of the British Welfare State (Nueva York: Palgrave Macmillan, 2003); Harris, The Origins of British Welfare State; Martin Gorsky and Sally Sheard, eds, Financing Medicine: The British Experience since 1750 (London: Routledge, 2006); Jerònia Pons and Javier Silvestre, eds, Los orígenes del estado de bienestar en España, 1900-1945 (Zaragoza: PUZ, 2010).
} 
historiography has highlighted the impact of the First World War on social demands, the strengthening of the labour movement and the development of democratic structures in many countries as the principal factors of this boom. Later, the Great Depression led to an increase in the responsibilities of the state. Moreover, it is also necessary to mention the role of international institutions such as the International Labour Organization (1919) and the International Social Security Association (1927) in the diffusion of social insurances. ${ }^{10}$

In the core of pioneer countries, all of them European (the United Kingdom, Germany, Denmark and Ireland), the four basic social insurances had already been introduced, with a high degree of effective coverage of the population by the late 1930s. ${ }^{11}$ On a second level, we find another group of European countries that had the four insurances, but which only maintained moderate levels of coverage (Norway, Sweden, Holland, Belgium, Italy, France, Austria, Luxembourg and Czechoslovakia). Other countries had, at best, incomplete systems because some social risks were not covered. This was the case of Spain, which had to wait until after the Spanish Civil War (1936-1939) to introduce compulsory sickness insurance. By then, 25 European

\footnotetext{
${ }^{10}$ For more on the role of these organizations in the expansion of insurance, see also Usui, 'Welfare State'. More on the controversies over private and social insurance within international organizations such as the International Labour Office (ILO), the International Social Security Association (ISSA) and the International Congress of Actuaries between 1900 and 1960 can be found in Martin Lengwiler, 'Competing globalizations: controversies between private and social insurance at International Organizations, 1900-60', in Robin Pearson, ed, The Development of International Insurance (London: Pickering and Chatto, 2010), 167-86.

${ }^{11}$ Quantitative information on these aspects can be found in Peter Flora, State, Economy and Society in Western Europe, 1815-1975 (Francfort: Campus Verlag, 1983); Ashford, La aparición; Köhler and Zacher, The Evolution of Social Insurance.
} 
countries, 6 Latin American countries, Japan and New Zealand had managed to pass laws providing protection against the risk of sickness. ${ }^{12}$

This article seeks to analyse a different case from the majority of European countries, namely, the introduction of an insurance that was essential for the welfare of the population, and for the future of the Spanish social security system, in a dictatorial framework and in a context of economic scarcity between 1939 and 1962. With this aim, the relationship between the political interests of the dictatorship, the system of financing and management adopted and the low degree of coverage attained are examined. The article is divided into three parts. The first section concentrates on the implementation of sickness insurance during the Franco dictatorship. The second section analyses the degree of coverage in terms of population and provisions. The third section deals with the direct management of the insurance and the system of collaborative agreements and the development of health care infrastructure.

In Spain, during the first third of the twentieth century, the first laws governing industrial accident insurance (1900); pensions (voluntary in 1909 and compulsory in 1919/1921); and maternity (benefits in 1923 and insurance in 1929/1931) had been promulgated; and a system of subsidised freedom was introduced to cover unemployment in $1933 .{ }^{13}$ Within this context, sickness insurance seemed to be only

\footnotetext{
${ }^{12}$ Alfonso Herranz, 'La difusión internacional de los seguros sociales antes de 1945', in Pons and Silvestre, Los orígenes, 51-84; Murray, Origins of American Health, 39-41.

${ }^{13}$ See the works collected in Pons and Silvestre, Los orígenes. For more on this period, see Juan I. Palacio Morena, La institucionalización de la reforma social en España, 1883-1924. La Comisión y el Instituto de Reformas Sociales (Madrid: Ministerio de Trabajo, 1988); Juan I. Palacio Morena, La construcción del Estado Social (Madrid: Consejo Económico y Social, 2004); Santiago Castillo, ed,
} 
a matter of time. However, the Spanish government neither legislated, regulated nor provided financing to cover this contingency before the outbreak of the Civil War. ${ }^{14}$ The state's responsibility was limited to protecting the public against any abuses or fraud committed by the different funds or societies providing private insurance, whether in terms of health care provision or of an economic nature. The slow development of private insurance companies and the state's inability to introduce compulsory sickness insurance meant that the greatest health care coverage in Spain during this period was the work of a cluster of friendly societies. In spite of their limited financial capacity, these societies helped to prevent many working-class families from falling victim to the vicious cycle of sickness-loss of income-poverty, which was most feared by the people at this time. ${ }^{15}$

Solidaridad, Seguridad, Bienestar. Cien años de protección social en España (Madrid: Ministerio de Trabajo e Inmigración, 2008).

${ }^{14}$ The state limited itself to granting ridiculous subsidies to a handful of friendly societies. See Margarita Vilar Rodríguez, 'La cobertura social a través de las sociedades de socorro mutuo, 18391935. ¿Una alternativa al Estado para afrontar los fallos de mercado?', in Pons and Silvestre, Los orígenes, 85-122 and 113-14; Jerònia Pons Pons and Margarita Vilar Rodríguez, 'Friendly societies, commercial insurance and the state in sickness risk coverage: the case of Spain (1880-1944)', International Review of Social History, 2011, 56 (1), 71-101.

${ }^{15}$ Coverage through friendly societies basically entailed insurance against loss of income during periods of sickness. This philosophy was not exclusive to the Spanish case, see Marco H. D. van Leeuwen, 'Historical Welfare Economics in the Nineteenth Century. Mutual Aid and Private Insurance for Burial, Sickness, Old Age, Widowhood, and Unemployment in the Netherlands' in Bernard Harris and Paul Bridgen, eds, Charity and mutual aid in Europe and North America since 1800, (New York, USA: Routledge, 2007), 89-130. For more on the Spanish case, see Margarita Vilar Rodríguez and Jerònia Pons Pons, 'El papel de las sociedades de socorro mutuo en la cobertura del riesgo de enfermedad en España (1870-1942)' (Proceedings of the Xth International Congress of Economic History, The Spanish Association of Economic History, Sevilla: Universidad Pablo Olavide, 2011) 
In the first decades of the twentieth century, there were various unsuccessful attempts to implement state sickness insurance. Why did the state fail when it came to establishing sickness insurance before the Civil War? Various factors hindered the introduction of the insurance. The most serious obstacles included an inefficient tax system, which curbed the possible increase in state income proceeding from direct taxes. This in turn impeded the creation of all the health care infrastructure needed to introduce sickness insurance for the entire population. ${ }^{16}$ On the other hand, the opposition continued from the majority of employers, medical associations andmutuals and insurance companies, who felt their private business interests to be at risk. Even workers showed themselves unwilling to accept an insurance based on contributions, as they were hoping for greater state coverage without having to pay contributions, as was the case with old age pensions.

Spanish historiography offers interesting studies on the attempts to introduce sickness insurance in the circumstances existing prior to the Civil War. A number of these studies focus on the political debate that was generated in Spain among the different social pressure groups linked to the implementation of health insurance (doctors, insurance companies, trade unions and political representatives). ${ }^{17}$ Other authors have concentrated on the progress of health care coverage during the period

${ }^{16}$ Francisco Comín, 'La economía española en el periodo de entreguerras (1919-1935)', in Jordi Nadal, Albert Carreras and Carles Sudrià, eds, La economía española en el siglo XX. Una perspectiva histórica (Barcelona: Ariel, 1987), 105-49.

${ }^{17}$ Isabel Porras Gallo, 'La profilaxis de las enfermedades infecciosas tras la pandemia gripal de 181819: Ios seguros sociales', Dynamis, 1993, 13, 279-93; Isabel Porras Gallo, 'Un foro de debate sobre el seguro de enfermedad: las conferencias del Ateneo de Madrid en 1934', Asclepio, 1999, 51, 159-84 
of left-wing government of the Second Republic. ${ }^{18}$ Finally, some works have attempted to explain the obstacles that hindered the introduction of compulsory sickness insurance in Spain during this period. ${ }^{19}$ Likewise, the implementation of compulsory sickness insurance during the first stage of the Franco regime has been dealt with in general works on the development of social security. ${ }^{20}$ However, the majority of these studies have only focused on certain aspects. On the one hand, there are works that have concentrated on a description of the origins and implementation of sickness insurance. ${ }^{21}$ On the other hand, there have been numerous studies of the National Welfare Institute (Instituto Nacional de Previsión, or INP) and the struggle to control it by the different 'families' of the Francoist regime (mainly social Catholics and Falangists). ${ }^{22}$ Other works, meanwhile, have concentrated on the Franco regime's changes in public health care policies. ${ }^{23}$

\footnotetext{
${ }^{18}$ Josep Bernabeu Mestre, 'La utopía reformadora de la segunda republica: la labor de Marcelino
} Pascual al frente de la Dirección General de Sanidad, 1931-1933)', Revista Española de Salud Pública, 2000, 74, 1-13; Esteban Rodríguez Ocaña, 'La asistencia médica colectiva en España hasta 1936', in José Álvarez Junco, ed, Historia de la Acción pública en España. Beneficencia y Previsión (Madrid: Ministerio de Trabajo y Seguridad Social, 1990), 321-61

${ }^{19}$ Pons and Vilar, 'Friendly societies' and Vilar and Pons, 'El papel de las sociedades'.

${ }^{20}$ The most recent include José L. Tortuero, ed, Cien años de protección social en España (Madrid: MTIN, 2007); Castillo, Solidaridad; Santiago Castillo and Rafael Ruzafa, eds, La previsión social en la historia (Madrid: Siglo XXI, 2009), 255- 63.

${ }^{21}$ Pedro González Murillo, 'La política social del franquismo: el seguro obligatorio de enfermedad'. Aportes, 2005, 57, 62-76; Pedro González Murillo, ‘El franquismo social: propaganda y seguros a través del Instituto Nacional de Previsión (1939-1962)', in Castillo, Solidaridad, 89-124.

${ }^{22}$ Arturo Álvarez Rosete, ‘¡Bienvenido, Mister Beveridge! El viaje de William Beveridge a España y la Previsión Social Franquista', International Journal of Iberian Studies, 2004, 17 (2), 105-116; Arturo Álvarez Rosete, 'Elaborados con calma, ejecutados con prisa. El avance de los seguros sociales y la 
All of these studies have shed light on the context in which compulsory sickness insurance was prepared in the 1940 s. $^{24}$ Few of these studies, however, have focused their interest on aspects related to the management of the insurance, largely undertaken by collaborating bodies, or on its cost. The majority of studies available have not included any in-depth analysis of the financing of compulsory sickness insurance, nor of the problems caused by the application of the plan for health care facilities. This plan was intended to create the infrastructures necessary to implement the insurance, but its problems intensified when medical and surgical specialities were incorporated. With regard to funding, it should be emphasised that during approximately the first ten years of compulsory sickness insurance the state played no part in its financing, which came almost entirely from the premiums paid by employers and workers, with, of course, a greater burden in reality for the workers at a time of a reduction in real wages and significant inflation. ${ }^{25}$

evolución del Instituto Nacional de Previsión en España entre 1836 y 1950', in Castillo and Ruzafa, La previsión social, 255-263; Emilio Majuelo, 'Falangistas y católicos-sociales en liza por el control de las cooperativas', Historia del Presente, 2004, 3, 29-43.

${ }^{23}$ Esteban Rodríguez Ocaña, 'The politics of public health in the state-managed scheme of healthcare in Spain (1940-1990)', in Ilana Löwy and John Krige, eds, Images of Disease. Science, Public Policy and Health in Post-war Europe (Luxembourg: European Communities, 2001), 187-210.

${ }^{24}$ The main statistical source for this article is the information stored in the INGESA archive. This archive contains documentation of the bodies responsible for health care management in Spain during the period under study. The quantitative and qualitative information has been supplemented with other reports and periodicals of the time.

${ }^{25}$ In both in agriculture and industry, real wages slumped over an extended period of time after the Civil War. See Margarita Vilar Rodríguez, Los salarios del miedo. Mercado de trabajo y crecimiento económico en España durante el franquismo (Santiago de Compostela: Fundación 10 de Marzo, 2009). 


\section{The implementation of compulsory sickness insurance (1939-1944)}

The serious health care crisis of the Spanish postwar period alarmed the Francoist authorities for two basic reasons. ${ }^{26}$ On the one hand, the catastrophic situation could put the country's public health at risk, which would tarnish the image of the victorious Francoist 'New State'. On the other hand, the health care crisis could threaten both the desired 'social peace' and the process of winning over the masses. Within this context, the Franco dictatorship used sickness insurance to legitimise its power, win the support of the masses and serve as a purveyor of propaganda to transmit its social concern. The social insurance system introduced under Franco had much in common with those functioning under the dictatorial regimes in Germany and Italy. The case of sickness insurance is a clear example of this proximity. The dictatorship in Spain adapted the comprehensive sickness insurance model in force in Nazi Germany, which was an insurance of the Bismarckian tradition, but strictly controlled by the state. Yet it also drew inspiration from the system of organisation prevalent in Italy. In other words, it was a system where a number of party-controlled agencies and institutions shared responsibility for its management. The result was a low level of coverage among the population and inadequate health care provisions. ${ }^{27}$

\footnotetext{
${ }^{26}$ The infant mortality rate was 115.3 per thousand in 1935 and 148.6 per thousand in 1941 , see Roser Nicolau, 'Población, salud y actividad', in Albert Carreras and Xavier Tafunell, eds, Estadísticas Históricas de España. Siglos XIX y XX (Madrid: Fundación BBVA, 2005), 79-154, 131. On the other hand, deaths from disease were obtained from the Anuario Estadístico de España, 1955, 751. For more detail on these aspects, see Jerònia Pons Pons and Margarita Vilar Rodríguez, 'Labour repression and social justice in Franco's Spain: the political objectives of compulsory sickness insurance (1942-1957)', Labor History, 2012, 53 (2), 245-67.

${ }^{27}$ Eric Owen Smith, The German Economy (London: Routledge, 1994) and Vera Zamagni, The Economic History of Italy, 1860-1990 (Oxford: Oxford University Press, 1993).
} 
The basic principles of the labour and social policy of the Franco dictatorship were clearly established during the first months of the Spanish Civil War (19361939). Immediately, all political and trade union activity was banned, trade union organisations and political parties were dissolved and their properties seized. ${ }^{28}$ Before the conflict had ended, the so-called 'Fuero del Trabajo' or 'Employment Code' (1938) laid down the guidelines for the functioning of the labour market which were to be in force during almost forty years of dictatorship. We can highlight three basic traits that characterise the system that was set up. First, the 'Fuero' designated the state as the supreme advisory body charged with the responsibility of establishing the basic rules of labour relations. The principal codes of conduct governing these relations centred on the duty of employers to take care of and protect their workers who, for their part, were expected to reciprocate with loyalty, discipline and subordination. Second, the legal framework was aimed at expelling married women from the labour market, while at the same time advocating a patriarchal family model where the man would have the responsibility of 'being the breadwinner'. ${ }^{29}$ Finally, the 'Fuero' established the grouping of employers and workers within a single vertical 'trade union' (sindicato vertical) at the service of the state under the principles of 'unity, totality and hierarchy'. This trade union structure had three main aims: to serve as an instrument of the state to help implement its

${ }^{28}$ Decree of 25 September 1936, BOE (Boletín Oficial del Estado or Official State Gazette) of 28 September 1936. Order of 10 January 1937, BOE of 11 January 1937 and Decree of 19 April 1937, BOE of 20 April 1937.

${ }^{29}$ Carmen Sarasúa and Lina Gálvez, eds., ¿Privilegios o eficiencia? Mujeres y hombres en los mercados de trabajo (San Vicente de Raspeig: Publicaciones de la Universidad de Alicante, 2003), 39. Although, in practice, economic necessity forced women to continue working in secrecy without guarantees or labour rights. 
economic policy, to do away with the class struggle and to impose a framework of discipline and control of the productive forces. ${ }^{30}$ Although the vertical trade union performed an important function in the dictatorship's repressive machinery, effective control over many of the workers was exercised directly by employers from within their own companies. This legal scenario completely destroyed the capacity of wage earners either to protest or to negotiate, while at the same time it made labour conditions tougher and reduced workers' purchasing power. The initial investment in terror brought the dictatorship great dividends in the long term, in terms of consent and control. ${ }^{31}$

With this background, the elaboration of the legal bases of the insurance and its implementing regulation was carried out amidst confrontations over the control of the National Welfare Institute. In the first stage, after its reconstitution in 22 August 1938, the Institute was under social-Catholic influence with a leading role of former members such as Luis Jordana de Pozas. However, from 1941 until mid-1945 (when fascism was defeated in a large part of Europe) there was a strong Falangist influence with the arrival of Minister Girón at the Ministry of Labour (1941-1957). ${ }^{32}$ The Falange - the only official and legal political party during the dictatorship 30 The law of 26 January 1940 on union unification ('Ley de Unidad Sindical', BOE of 31 January 1940) converted the FET y JONS into the only organisations authorised to channel labour conflict.

${ }^{31}$ Paul Preston, Caudillo de España (Barcelona: Grijalbo, 1994), 971. The law on state security of 29 March 1941 (BOE of 11 April 1941) also contributed its dose of terror by punishing subversive and anti-patriotic behavior with the death penalty.

${ }^{32}$ For this period, see Pedro González Murillo, 'El mutualismo laboral como expresión del fracaso en la implantación de los seguros sociales', in E. Baena and F. J. Fernández, eds, Tercer Encuentro de Investigadores sobre el Franquismo y la Transición (Sevilla: Muñoz Moya editor, 1988), 329-37; Carme Molinero, La captación de las masas. Política social y propaganda en el régimen franquista (Madrid: Cátedra, 2005); Majuelo, 'Falangistas'; Álvarez Rosete, 'Elaborados con calma'. 
promoted the compulsory sickness insurance (Seguro Obligatorio de Enfermedad, or SOE), passed by the Law of 14 December 1942, as something of their own, excluding the National Public Health Department - in the hands of Catholic and monarchist military circles - which was left to run preventative campaigns, including the fight against tuberculosis. The power struggles between the different factions of the Franco regime, in which the Falangists initially prevailed, determined the success of some health care projects, such as the approval of the Silicosis Scheme (1941), or the failure of others, for example such as the tuberculosis insurance programme. ${ }^{33}$

On 25 July 1941, just a few days after taking charge of the Ministry of Labour, José A. Girón de Velasco signed a decree creating a commission responsible for drawing up a preliminary draft law for compulsory sickness insurance. ${ }^{34}$ The commission comprised the Director-General for Welfare, three directors of the National Welfare Institute, one of whom would be a representative of the National Syndicalist Federation, the Commissioner of the National Welfare Institute, and representatives of the National Public Health Department, the National Antituberculosis Board, the General Council of Medical Colleges and the 'Obra 18 de Julio' - an organisation linked to the Falangist union. ${ }^{35}$ The commission also included

\footnotetext{
${ }^{33}$ The Law of 14 December 1942 was published in the BOE of 27 December 1942. Jorge Molero Mesa, 'Enfermedad y previsión social en España durante el primer franquismo (1936-1951). El frustrado seguro obligatorio contra la tuberculosis', Dynamis, 1994, 14, 199-225; Alfredo MenéndezNavarro, 'The politics of silicosis in interwar Spain: Republican and Francoist approaches to occupational health', Dynamis, 2008; 28, 77-102; Álvarez Rosete, 'Mister Beveridge'.

${ }^{34}$ Decree of 11 June 1941 . BOE of 12 July $1941,5587$.

${ }^{35}$ The National-Syndicalist conception of health care led the National Labour Delegation (Delegación Nacional de Sindicatos) to create, on 9 October 1940, the so-called Obra Sindical 18 de Julio, as the organisation responsible for developing the social aspect of health care policy. The Obra Sindical 18
} 
the National Welfare Institute's actuary, a doctor from the National Fund for Industrial Accidents and the chief physician of the National Welfare Institute's maternity and child foundation, the 'Obra Maternal e Infantil'. The commission drew up a preliminary draft law for the insurance over a period of two years and transferred it to the Council of State, where it was approved on 11 November 1943.

The commission met for the first time at the National Welfare Institute headquarters on 1 August (1941) and, after a pondered study, presented the preliminary draft law to the Minister on 4 May 1942. The preliminary draft law determined the risks to be covered by the proposed sickness insurance; its structure, economic provisions, indemnities and health care provisions, as well as the resources required and the viability of its management. Subsequently, a new special commission constituted by an Order of 28 October 1942 revised the preliminary draft law, introduced slight modifications and considered its mission accomplished in early December. $^{36}$ Shortly afterwards, the law of 14 December 1942 was published, creating compulsory sickness insurance, and the National Welfare Institute was given a period of six months to draw up the regulation of the law. ${ }^{37}$ The Institute fulfilled the mandate within the deadline. In July 1943, while Europe was embroiled in the Second World War, a National Welfare Institute delegation went abroad with the aim of studying the administrative organisation of sickness insurance in countries that

de Julio initially channelled its activities into three major sections: general health care, medical assistance and occupational health care. In this initial period, the Obra Sindical 18 de Julio fulfilled two important functions: implementing the health care and social policy of the National Movement and the provision of medical and pharmaceutical care to low-income workers.

\footnotetext{
${ }^{36}$ The characteristics of this commission can be consulted in the BOE of 6 November 1942, 9005.

37 The law creating compulsory sickness insurance was published in the BOE of 27 December 1942, 10592-97.
} 
had already implemented it. During their trip they visited Germany and other countries under Axis influence such as the Protectorate of Bohemia and Moravia, Austria, Slovakia, Hungary, Romania and Bulgaria, returning to Spain in September. The information gained allowed the draft regulation of compulsory sickness insurance to be completed before its transfer to the Council of State, where it was approved on 11 November $19433^{38}$

Shortly after the passage of the regulation, in December 1943, the National Sickness Insurance Fund (Caja Nacional del Seguro de Enfermedad) was created with the initial task of organising its work and outlining its administrative procedure over the next five months. The affiliation process was initiated in May 1944, and in September of the same year entitlement to receive benefits came into force. ${ }^{39}$ Compulsory sickness insurance was the responsibility of the National Welfare Institute, as the sole insurer. Nevertheless, companies could choose whether their staff received the medical services provided under the insurance through the Obra 18 de Julio or, always under direct agreement with the National Welfare Institute, through state, provincial, municipal or private institutions. In the latter case, a favourable (ideological) report by the aforementioned Obra was required. ${ }^{40}$

The implementation of compulsory sickness insurance had to overcome serious obstacles, which compelled its progressive introduction in two stages. ${ }^{41}$ During the

\footnotetext{
${ }^{38}$ The regulation of the law on compulsory sickness insurance was published in the BOE of 28 November 1943, 11427-36.

${ }^{39}$ Boletín de Información del Instituto Nacional de Previsión (BIINP), 1945 (1), 21-29.

${ }^{40}$ BOE of 27 December 1942, 10594 and BOE of 1 July 1944, 5112-13.

${ }^{41}$ Compulsory sickness insurance regulation, BOE of 18 November 1943, 11436. As a result, the sickness insurance emerged as a means of providing access to health care through the provision of diverse medical and pharmaceutical services and not merely as a form of income protection.
} 
first years only domiciliary care would come into effect, and later, specialist care and hospital services. Thus, general medical care and pharmaceutical treatment would be provided when the insurance first came into force, for a maximum period of 26 weeks a year for the insured and 13 for their family members. ${ }^{42}$ Specialities and hospital services were scheduled to become operational after a period of two years, although in the end they were not incorporated until 1947-1948. Specialist medical care and hospital services were then offered to insured and families up to a limit of 12 and 6 weeks respectively. The main obstacles to the introduction of compulsory sickness insurance were inadequate infrastructure, the financial requirements and the need to win over pressure groups that were historically opposed to this insurance.

In fact, the first step to be taken was to organise medical and pharmaceutical services, overcoming the reticence that these professional groups felt towards the public health care service. The problem of winning support for the introduction of compulsory health insurance among doctors, who feared a drop in their professional income, was successfully dealt with by inviting representatives of the medical profession to collaborate in preparing the legislation, to a massive offer of public employment and to higher medical fees. According to what can be deduced from the information provided by Sebastián Criado del Rey, director of the National Sickness Insurance Fund in 1947, representatives of the medical profession were invited to participate in the drafting committee of the bill (7 of the 14 members were doctors), in the commission of the draft regulation (10 of the 26 members were doctors, and another 3 were pharmacists) and in the liaison committee of article 28 of the law of

\footnotetext{
${ }^{42}$ BIINP, 1944 (11), 1396-98.
} 
1942 (9 of the 14 members were doctors and 1 was a pharmacist), all of which dealt with matters relating to the appointment of doctors, family quotas and fees.

Meanwhile, a system of authorisation was created for doctors to attend those insured under compulsory sickness insurance, based on making a limited number of doctors public employees. Efforts were made to incorporate doctors in rural areas into the insurance, and also some doctors working in private medicine. Later, doctors from the Falangist organisation Obra 18 de Julio and the National Welfare Institute's Obra Maternal e Infantil were also included. The initial estimate was that 16,000 doctors would be incorporated into the scheme, whose annual salaries would be, according to the National Welfare Institute's own figures, between 20,000 and 22,500 pesetas for doctors with 500 families (upper limit) and 15,750 pesetas for doctors with 350 families, higher than those offered by other state bodies or under the socalled system of 'igualas'. ${ }^{43}$ As regards pharmacists, an agreement was signed between the council of the National Welfare Institute and the General Council of Pharmaceutical Associations regulating the provision of pharmaceutical services under compulsory sickness insurance. The insurance took responsibility for all pharmaceutical provisions and pharmacies were obliged to dispense all prescriptions issued by the doctors of the compulsory insurance scheme. ${ }^{44}$

\footnotetext{
${ }^{43}$ In rural areas, some doctors, besides taking responsibility for the medical care of those included in the census of the poor, also offered private cover to the rest of the population in return for payment by means of a system of agreed retainer fees (known as 'igualas'). This service, however, did not include any pecuniary compensation and lacked the provision of services in medical-surgical specialities. See Pons and Vilar, 'Friendly societies'; Sebastián Criado del Rey, Problemas sanitarios del seguro de enfermedad (Madrid: INP, 1947), 28-32. See also the Order of 16 May 1944, BOE of 22 May 1944, 4010 and the Order of 26 June 1944, BOE of 28 June 1944, 5027.

${ }^{44}$ Decree of 11 November 1943. BOE of 18 September 1943, 11430 and BIINP, 1944, 10, 1318.
} 
Second, applying the compulsory sickness insurance required a great economic investment, as its functioning demanded substantial expenditure on infrastructure and human and material resources. Compulsory sickness insurance, therefore, the cornerstone of the Franco regime's social policy propaganda, was faced with enormous problems due to the state's lack of resources, a result of the postwar economic crisis, autarky and the regressive tax system. The lack of resources conditioned both the management of the scheme and the required health care infrastructure. Agreements signed with private entities, which used their own human resources and health care infrastructure, were crucial in overcoming these obstacles.$^{45}$ It must be borne in mind that compulsory sickness insurance was set up under a general pay-as-you-go system, which meant that it covered provisions with the premiums collected that same year. ${ }^{46}$

The financial problem was overcome during the first ten years with funds from other insurances, which supplied a start-up capital of 50 million pesetas and a system of contributions in which employers and workers paid a premium for insurance coverage, with practically no contribution whatsoever from the state (Table 1). ${ }^{47}$ By an order of 3 June 1944, a premium was fixed equivalent to 5.013 percent of earned income, to be paid equally between employers and workers - although

\footnotetext{
${ }^{45}$ Decree of 2 March 1944 and BIINP, 1945, 1, 29.

46 'Características del Seguro español de enfermedad', Speech delivered by the Commissioner of the National Welfare Institute, Luis Jordana de Pozas to the Círculo de la Unión Mercantil de Madrid on 20 May 1944, BIINP, 1944, 5, 619.

47 The start-up capital was obtained proportionally out of the surpluses of the different insurances in effect in Spain on 31 December 1942. The loans were made in cash and, although they were interest free, they had to be repaid within ten years of the third year of implementation of compulsory sickness insurance. BIINP, 1944, 6, 853.
} 
proportionally a greater burden for the latter - which in practice constituted the main source of financing for compulsory sickness insurance (Table 2). Of the total proceeding from the contributions of workers and employers, 2.45362 percent was then deducted to contribute towards the inspection of health services.

\section{INSERT TABLES 1 AND 2 ABOUT HERE}

The rush - due to the political objectives of the insurance - also obliged the creation of some limits in terms of membership. In the first stage of the insurance, compulsory registration was only established for all employees over the age of 14 (the minimum age for employment at that time) whose earned income did not exceed a very limited amount: 9,000 pesetas/year. This limit was raised to 12,000 pesetas in 1948 and 18,000 pesetas in $1949 .^{48}$ Workers with earnings over the established limits lost the condition of compulsorily insured, but could join or continue with the insurance as voluntarily insured by paying the full premium. The income limit was not the only entry barrier to the benefits of compulsory sickness insurance, as some groups of workers were only incorporated later. This was the case of casual workers, home workers, seamen or agricultural workers, who had social insurance under their own special schemes. ${ }^{49}$

\section{Membership, coverage and management of compulsory sickness insurance} (1939-1962)

\footnotetext{
${ }^{48}$ Amount in current pesetas. Compulsory sickness insurance regulation, BOE of 28 September 1943. Joaquín García Murcia and M. Antonia Castro Argüelles, eds, Legislación Histórica de Previsión Social (Pamplona: Aranzadi-Gobierno del Principado de Asturias, 2009), 185. For the increases in wage limits, see the Order of 9 March 1948 and the Decree of 1 July 1949.

${ }^{49}$ Decree of 29 April 1959 and Decree of 2 March 1961, BOE of 14 March 1961.
} 
The law of 1942 assigned the role of introducing, managing and administrating the insurance to the National Welfare Institute and the organisation of medical services to the Obra 18 de Julio. However, in 1944, the Institute had neither sufficient staff to cope with the bureaucratic aspects of management nor enough health care centres. In 1944 there were 353 centres (clinics and outpatient centres) available for compulsory sickness insurance. These belonged to the National Welfare Institute, the National Public Health Department, the Obra Maternal e Infantil and there were also industrial accident clinics, but the insurance lacked its own centres. ${ }^{50}$ In view of this situation, a decree was issued on 2 March 1944, which created a system of collaboration with private entities for managing compulsory sickness insurance. Nominally, the insurance remained in the hands of the National Welfare Institute, but in reality the National Sickness Insurance Fund was authorised to delegate its managerial powers to private entities which, if they met certain requirements, could be designated collaborating bodies. By January 1945, 180 special agreements had been signed, corresponding to 120 mutual societies, 6 'montepíos' (similar to friendly societies), 12 'igualatorios' (doctors' associations), 8 commercial companies, 32 company funds and 2 federations. ${ }^{51}$ With regard to direct insurance, this was covered by medical services operating through the Obra 18 de Julio. In addition, the National Sickness Insurance Fund signed an agreement with the National Labour Delegation by which the former benefited from the network of correspondents of the union

\footnotetext{
${ }^{50}$ Instituto Nacional de Previsión, El seguro de Enfermedad y sus problemas: estudio para un plan general de instalaciones de asistencia médica (Madrid: Ministerio de Trabajo, 1944).

${ }^{51}$ BIINP, 1945, 2.
} 
welfare organisation 'Obra Sindical de Previsión', which had a wide diffusion in rural areas. $^{52}$

In the decree of 2 March, the implementing rules were established for the special agreement between the National Welfare Institute and the private entities. The collaborating bodies had to pay a deposit, take responsibility for the quarterly collection of premiums (from workers and employers) and, after deducting benefits and administration costs, pay the surplus into the National Fund. The collaborating bodies were obliged to allocate part of the premiums collected to the following items: a) administration costs; b) inspection of health services; c) reserve requirements; and d) Health Care Facilities Plan. Furthermore, the administration costs of collaborating bodies operating on a national scale were initially set at 25 per cent of the amount collected, a figure that dropped to 20 per cent in 1947 and to 16.20 per cent in $1948 .^{53}$ Likewise, statutory reserves were established that could not exceed 10 per cent of premiums. Between 1947 and 1950 these reserves were set at 5 per cent.

The main collaborating bodies included welfare mutuals, employers' industrial accident mutuals, a smaller number of medical 'igualatorios' and some company funds. The role of the employers' mutuals, in particular, should be emphasised. They had been created in Spain from 1900 onwards to cover industrial accidents. ${ }^{54}$ They had opened dispensaries and clinics to attend to workers who had suffered an accident and these could be exploited for sickness coverage. However, few friendly societies or welfare mutuals were able to participate in these agreements after the

\footnotetext{
${ }^{52}$ BIINP, 1945, 1, 21-29.

${ }^{53}$ BOE of 13 January 1947, BOE of 11 January 1948 and BOE of 3 February 1948.

${ }^{54}$ For the role of employers' industrial accident mutuals in the management of compulsory sickness insurance, see Jerònia Pons Pons, 'El seguro obligatorio de enfermedad y la gestión de las entidades colaboradores (1942-1963)', Revista de la historia de la economía y de la empresa, 2010, 4, 227-48.
} 
law on mutual societies of 1941 , due to the need to pay a deposit and the limited health care infrastructure they had managed to create.

The agreements were signed in 1945 for a period of ten years. An analysis of membership during this first decade of their implementation reveals an even distribution of affiliated companies between direct insurance and collaborating bodies (Table 3). Yet if the insured and the beneficiaries are examined, it is evident that the collaborating bodies achieved approximately 75 per cent of coverage. This would therefore suggest that the companies covered by direct insurance (that is, the National Fund and union services) were smaller, with fewer workers, and that these in turn had smaller families. The number of companies covered by direct insurance increased over time until it reached 60 per cent of the total, while the proportion of insured and beneficiaries grew to 40 per cent.

\section{INSERT TABLE 3 ABOUT HERE}

Four months after its implementation, in December 1944, only one quarter of the Spanish population was beneficiary of the compulsory sickness insurance. The percentage of coverage against sickness grew slowly in the following decade until it reached 35 per cent of the population by 1957. In this respect, the fact that compulsory membership only existed for permanent industrial workers in the first stage must be taken into account. This meant that almost 50 per cent of Spain's active population, who were still engaged in agriculture in 1950, were left unprotected, among others. ${ }^{55}$ For all practical purposes, the situation did not begin to change until the creation of the national agricultural security service, the Servicio

\footnotetext{
${ }^{55}$ In 1950 agricultural workers accounted for $47.6 \%$ of Spain's total working population. Details in Nicolau, 'Población', 150.
} 
Nacional de Seguridad Agraria, in 1958 and a national mutual society for agricultural insurance, the Mutualidad Nacional de Previsión Agraria, in 1959. ${ }^{56}$.

Eighty per cent of the workers affiliated to compulsory sickness insurance were men, which is hardly surprising in a context of employment discrimination against married women. ${ }^{57}$ The distribution of members of the insurance scheme was also unequal in demographic terms. The more industrialised provinces logically had a higher coverage rate. ${ }^{58}$

To extend the insurance, the National Welfare Institute used the media influence of the dictatorship's single official trade union, which acted as an improvised insurance agent in a situation where joining the union was mandatory for the majority of workers. Furthermore, the National Welfare Institute put pressure on the members of other insurance schemes to persuade them to choose the National Fund. ${ }^{59}$ For their part, the collaborating bodies tried to use their own marketing resources efficiently. However, insurance agents were prohibited from receiving commission for the contracting of compulsory sickness insurance. Various factors can explain the collaborating bodies' higher levels of membership (Table 4): a) the risk selection policy of some of the collaborating bodies, which were able to reject certain companies (the National Fund had to accept all applicants), while attempting to recruit members with a smaller number of beneficiaries and with higher wages; ${ }^{60}$

\footnotetext{
${ }^{56}$ González Murillo, ‘Franquismo social’, 97-98.

${ }^{57}$ For more on these aspects, see Vilar, Salarios del miedo, and the bibliography given there.

${ }^{58}$ Instituto Nacional de Previsión, Servicio de Prestaciones Sanitarias. Informe sobre la explotación de las instalaciones sanitarias del seguro de enfermedad (Madrid: INP, 1959).

${ }^{59}$ Archivo General de la Administración, Sindicatos, Caja 13/R-349.

${ }^{60}$ Instituto Nacional de Previsión, Caja Nacional del Seguro de Enfermedad. Prestaciones (Madrid: INP, 1950).
} 
b) employers preferred their own institutions where, especially in the case of larger companies, they had more influence on the board of directors; and c) influence over doctors and, therefore, control over sick workers could be exercised more directly in the collaborating bodies.

\section{INSERT TABLE 4 ABOUT HERE}

The total cost of the provision of compulsory sickness insurance was distributed between direct insurance and the collaborating bodies in the same proportion as the number of insured and beneficiaries. Direct insurance paid approximately 25 per cent of provisions compared with almost 75 per cent paid by collaborating bodies (Table 4). Between 1946 and 1952, the greatest expenditure was on health care provision. Both in direct insurance and in the collaborating bodies, economic benefits never exceeded 19 per cent and over time they showed a declining trend with respect to health care provisions.

\section{The increase in the cost of the insurance and the appearance of a deficit}

During the first years of the introduction of this mixed management model for compulsory sickness insurance the cost of the insurance increased. This rise was the result of the increase in items related to health expenditure, caused by the extension of coverage and the increase in medical fees due to hiring specialists, surgeons and health care assistants in order to offer medical specialities and provide hospital care, as well as the growth in pharmaceutical consumption resulting from the dissemination of new medicines and the fact that these were free. The largest health expenditure items were paying the fees of medical and health care staff (Tables 5 and 6). In 1946, this segment accounted for 51.75 per cent of expenditure in direct insurance and 52.9 per cent for the collaborating bodies. That same year, 
pharmaceutical costs accounted for 35.27 per cent and 36.13 per cent respectively, and hospital expenses 2.9 per cent in direct insurance and 0.6 per cent for the collaborating bodies. This difference was possibly due to the lack of state hospital infrastructure available for the provision of sickness insurance, which led to the need to resort to special agreements, with the consequent increase in costs. The most outstanding aspect, however, was the increase in pharmaceutical costs, which caused serious problems for the provision of compulsory sickness insurance in the medium term. In 1952, pharmaceutical costs were approaching 50 per cent of sickness insurance provisions both in direct insurance and in the agreements with collaborating bodies. The tremendous growth in pharmaceutical costs was due to the fact that benefits covered the full cost of medical prescriptions, and to the consumption of new medicines such as antibiotics. Furthermore, abuse and fraud in the issuing of prescriptions further increased expenses.

\section{INSERT TABLES 5 AND 6 ABOUT HERE}

The extension of compulsory sickness insurance provisions was undertaken in different stages. In the first, which lasted until January 1947, coverage was limited to family medicine. The second stage was initiated with a decree of 29 December 1946, which extended provisions to general surgery and surgical hospitalisation, ophthalmological, otorhinolaryngologic and radiological care and clinical analysis as a diagnostic tool. The service of doctors' assistants known as 'practicantes' was also included. Later, by an order of 28 July 1951, thoracic surgery and cardiovascular specialities were created. One year later, on 21 June 1952, other branches of surgery were included, such as the fields of urology, otorhinolaryngology, traumatology and orthopaedics, as well as general surgery and radiotherapy 
services. In the same year the night-time emergency service was established and medical care was about to be extended to Sundays and public holidays. ${ }^{61}$

The plans for extending compulsory sickness insurance and the levels of coverage of the insurance were tied to the development of the health care infrastructure based on outpatient clinics (known as 'ambulatorios') and large hospitals (known as 'residencias sanitarias'). The National Health Care Facilities Plan was passed by means of an order of 19 January 1945. The initial plan envisaged 86 large hospitals with a total of 24,000 beds, 149 large outpatient clinics, 110 smaller outpatient clinics and 73 maternity institutions. The development phase was to last 10 years and had a budget of 1,000 million pesetas. Just one year later the plan had to be revised with estimates more in line with the economic reality of the country. The number of large hospitals projected was reduced to 68 and large outpatient clinics to 62 , while the number of smaller outpatient clinics was increased to 144 . The maternity institutions contemplated in the initial plan disappeared and they were integrated into hospitals except for one in Madrid. In 1953, after the plan had been in force for almost a decade, there were only nine large hospitals up and running: in La Coruña, Guadalajara, Valencia, Puertollano, Calatayud, Logroño, Santa Cruz de Tenerife, Teruel and Huelva, and 18 outpatient clinics. In May 1954, another nine were under construction, a figure that was a far cry from the 68 large hospitals originally envisaged. ${ }^{62}$ The construction of outpatient clinics and hospitals in this first

\footnotetext{
${ }^{61}$ For example, for the case of Madrid, see 'Los nuevos servicios del Seguro de Enfermedad', Revista del Seguro de Enfermedad, 1952, 1 (9), 3-4.

62 This building work was in the hands of just a few companies in the sector. The most important included: Eguinoa Hermanos; R. Beamonte; Agromán y Huarte y cía. See 'Situación de las obras del Plan Nacional de Instalaciones del Seguro de Enfermedad, en fin de mayo de 1954', Revista Española del Seguro de Enfermedad, 1954, 2 (4), 47-48.
} 
decade was jointly financed by employers and workers. From 9 January 1947, managers of compulsory sickness insurance were obliged to pay 1.5748 per cent of premiums collected into the National Sickness Insurance Fund, a percentage that was virtually doubled to 3.125 per cent by an order of 23 January 1948 .

The Health Care Facilities Plan was developed slowly due to the lack of public financing and the financial dependence on the income from premiums paid by employers and workers. These contributions were clearly insufficient, so the government passed a decree on 11 January 1952 authorising the National Welfare Institute to issue bonds in order to meet the needs of the health care facilities planned for compulsory sickness insurance. ${ }^{63}$ The number of beds was increased, above all from 1954 onwards, when the first large hospitals to be completed started functioning (Table 7). The number of beds available under the plan increased from 2,619 in 1954 to 5,713 in 1955 . There was a further increase in 1956 with 8,144 beds, and the number stabilised at 8,952 in 1957 and 1958 . The greater supply of hospital services increased the number of hospital stays among the insured, which ended up affecting the cost of compulsory sickness insurance provisions. By 1957, there were a total of 13,000 beds available for compulsory sickness insurance (of these, 3,564 were beds in clinics belonging to collaborating bodies). This was still a far cry from the 17,000 newly-created beds envisaged by the National Health Care Facilities Plan in $1947 .^{64}$ Despite the fact that the number of beds increased, these were poorly distributed geographically, as hospital infrastructures had not been built in the areas where the need for beds was most acute. This was due to the fact that

\footnotetext{
${ }^{63}$ BOE of 16 February 1952.

${ }^{64}$ Instituto Nacional de Previsión, Servicio de Prestaciones.
} 
the construction of these infrastructures responded more to political interests than to health care requirements.

\section{INSERT TABLE 7 ABOUT HERE}

In 1955, the mixed management system, based on financing that was supported almost exclusively by workers' and employers' contributions, was in a deficit situation. The collaborating bodies had experienced difficulties after the first years of management. The problems were the result of various factors: a) the increase in expenses due to the extension of the insurance; b) the reduction in the percentage of premiums that could be allocated to administration costs; ${ }^{65} \mathrm{c}$ ) the complex bureaucratic system established by the National Fund; and d) the debts incurred with the National Welfare Institute with regard to the Health Care Facilities Plan and the Inspection of Health Services. The collaborating bodies, unlike direct insurance, and due to the conditions inherent in the special agreements, could not show a deficit in their annual accounts, and therefore had to assume the deficit themselves. By 1953, the financial situation of compulsory sickness insurance had become critical for both direct and private management. In the case of direct insurance, the average premium per insured had risen from 7.39 in 1944 to 41.46 in

\footnotetext{
${ }^{65}$ Between 1946 and 1948, the percentage of the premium that the collaborating bodies operating on a national scale could allocate to administration costs fell from 25 to 16.2 per cent. In particular, the government determined what percentage of the premium could be retained by the collaborating bodies. This percentage was set according to the geographical scope of the collaborating insurance provider. It was not so much the result of an actuarial calculation as a political one. After the private management of sickness insurance had been operating for a while, the government tended to lower this percentage because many voices considered that this administration should not be profit making.
} 
1951 (in current pesetas). The cost of provisions per insured family, however, had increased from 1.94 to 43.25 pesetas. $^{66}$

Generally speaking, it appears that the causes of the deficit were the increase in pharmaceutical costs and doctors' fees, the financing of the Health Care Facilities Plan and the management of the collaborating bodies, which were accused of putting their commercial interests first. In 1949 a financial adjustment was introduced based on three measures: increasing premiums by 1 per cent, extending the insurance up to a wage limit of 18,000 current pesetas and establishing a new system of proportional contributions. However, in spite of this adjustment, the measures did not reverse the trend and the financial imbalance continued to grow. In 1954, when the first special agreements came to an end, the population of beneficiaries was restricted and efforts were made to persuade the collaborating bodies to participate in the upkeep of public hospitals and outpatient clinics. Under these circumstances, the principal collaborating body, Mutua General de Seguros, decided to renew the agreement, but in much worse conditions than the 1945 agreement. It had to pay a deposit of 14.1 million pesetas (10 per cent of premiums) and, while it could continue charging 9 per cent of wages as a contribution, the percentage of administration costs fell to 13 per cent. Furthermore, it was still not allowed to publish balance sheets showing a deficit, and it declared a debt to the National Welfare Institute of 52.7 million pesetas. ${ }^{67}$ The second most important collaborating body, Mapfre, for its

\footnotetext{
${ }^{66}$ Instituto Nacional de Previsión, I Asamblea General del Instituto Nacional de Previsión, Sección III. Diversos problemas actuales del Seguro de Enfermedad y de su Plan Nacional de Instalaciones (Madrid: INP, 1953), 20.

${ }^{67}$ Pons Pons, 'Seguro obligatorio'.
} 
part, decided not to renew, as management of compulsory sickness insurance had already caused losses of 26 million pesetas. ${ }^{68}$

\section{INSERT TABLES 8 AND 9 ABOUT HERE}

The direct insurance managed by the National Welfare Institute had a balance sheet showing losses in 1954 and 1955 (Table 8). In 1954 these losses were 26 million pesetas, a figure that almost tripled in 1955, when the deficit of compulsory sickness insurance reached 74 million. In the next two years the insurance needed a financial injection of 220 million and 64 million pesetas respectively, money that came from other social insurances. For its part, the state was compelled to increase its contribution, although its transfers to compulsory sickness insurance were limited to 21 and 27 million pesetas in 1954 and 1955. Nevertheless, the enormous deficit in the latter year forced the state to make a greater financial effort with a contribution of 390 million pesetas in 1956, which enabled the deficit to be eliminated. The collaborating bodies also had to receive an important state contribution in 1956 (Table 9). This situation clearly demonstrated that the financing model based mainly on workers' and employers' contributions was unviable. With the changes in the government at the end of the decade a new technocratic stage was initiated. The change of Labour Minister (Girón was replaced by Fermín Sanz Orrio) sparked off a reorganisation of the National Welfare Institute and the preparation of a National Social Security Plan in the 1960s. ${ }^{69}$

\footnotetext{
${ }^{68}$ Ignacio Hernando de Larramendi, Así se hizo Mapfre. Mi tiempo (Madrid: Actas Editorial, 2001), 235.

${ }^{69}$ For more on the period of change during which the new law was prepared, see M. Esther Martínez Quinteiro, 'EI INP entre 1957-1978: de los seguros sociales a la seguridad social franquista', in Castillo, Solidaridad, 265-88.
} 


\section{Conclusions}

Two main conclusions can be drawn from the analysis of the introduction and economic management of compulsory sickness insurance in Spain. First, the implementation of sickness insurance after the Civil War served as one more propaganda tool for the dictatorship in order to control workers, win over the masses and legitimise its power in a context of economic crisis and repression. ${ }^{70}$ In this context, the level of coverage of the population and provisions offered remained low. Second, sickness insurance, based on funding through workers' and employers' contributions and under mixed management in the hands of the National Fund and the collaborating bodies had a substantial deficit after ten years in force. The lack of financing by the state, the increase in pharmaceutical costs and medical fees and the plans to create large hospitals virtually brought the system to a standstill in the mid1950s. In 1945 the plan for health care facilities had set an ambitious goal, aiming to build 86 large hospitals throughout Spain in a period of 10 years. However, just one year later this target had been reduced to 68 . The results were much worse than expected. By 1953 only 9 of the 68 hospitals envisaged were operational, and the majority of these were relatively small and in areas where the demand for hospital beds was less. This investment, along with the increase in medical fees after the incorporation of a large number of family doctors and specialists, and the rising expense of free medicines, led to the appearance of deficits from 1954 onwards. Part of this failure was passed onto the collaborating bodies. In 1955 the system of special agreements for these bodies was reformed, bringing in tougher tax measures with regard to their management. The underlying problem, however, was that the mixed management model was based almost exclusively on financing from workers'

\footnotetext{
${ }^{70}$ For fuller information on this aspect, read Pons and Vilar, 'Labour repression', 245-67.
} 
and employers' contributions. The investment in fixed capital together with the increase in current expenditure caused a shortfall in funds and the need for public contributions. In the late 1950s a debate was already underway about a reform of the system which would lead to the public management of sickness insurance in Spain.

There was an attempt to solve the serious financial situation by passing the Basic Law of Social Security in 1963. The main objective was to introduce a unitary and integrated model of social protection, on a pay-as-you-go financial basis, with public management and state participation in financing (principles also taken on board by the General Social Security Law of 1966). However, these objectives were not met, as the old contributory systems remained in place while the lack of periodic revaluations and the state's inadequate financial commitment continued. Furthermore, the trend towards the unity of social insurance in terms of management and financing did not materialise, as a multitude of overlapping institutions survived. Spain had to wait until the end of the dictatorship and the adoption of the democratic Constitution (1978) in order to enjoy the benefits of an integrated, rational and transparent social security system which included sickness risk coverage. 
Table 1. Origin of start-up capital of compulsory health insurance (in current pesetas)

\begin{tabular}{|l|r|r|}
\hline Insurance & \multicolumn{1}{|c|}{ Surpluses } & \multicolumn{1}{c|}{ Loans } \\
\hline Extinct Retirement Pension & $4,385,969.29$ & $1,333,512.65$ \\
\hline Maternity & $4,323,204.35$ & $1,314,399.17$ \\
\hline Accidents & $8,622,490.08$ & $2,621,586.81$ \\
\hline Family Allowances & $143,586,748.42$ & $43,656,198.65$ \\
\hline Old Age Allowance & $3,533,418.52$ & $1,074,302.62$ \\
\hline Total & $164,451,730.63$ & $50,000,000.00$ \\
\hline
\end{tabular}

Source: Boletín de Información del Instituto Nacional de Previsión (BIINP), 1944, IV (6), 991.

Table 2. Initial premiums for compulsory health insurance (in current pesetas)

\begin{tabular}{|c|c|c|c|c|c|c|}
\hline Wage type & $\begin{array}{l}\text { Basic } \\
\text { wage }\end{array}$ & $\begin{array}{c}\text { Premium } \\
(\%)\end{array}$ & Day & Half week & Week & Month \\
\hline I & 6 & \multirow{7}{*}{5.01} & 0.30 & 0.90 & 1.80 & 7.60 \\
\hline II & 9 & & 0.45 & 1.40 & 2.70 & 11.30 \\
\hline III & 12 & & 0.60 & 1.80 & 3.60 & 15.10 \\
\hline IV & 15 & & 0.75 & 2.30 & 4.60 & 18.80 \\
\hline $\mathrm{V}$ & 20 & & 1.00 & 3.10 & 6.10 & 25.10 \\
\hline $\mathrm{VI}$ & 25 & & 1.25 & 3.80 & 7.60 & 31.40 \\
\hline VII & 30 & & 1.50 & 4.60 & 9.10 & 37.60 \\
\hline
\end{tabular}

Source: BIINP, 1944, IV (6), 853.

Table 3. Management of compulsory sickness insurance (1945-62)

(in current pesetas)

\begin{tabular}{|c|c|c|c|c|c|c|c|c|c|}
\hline & \multicolumn{3}{|c|}{ Member companies } & \multicolumn{3}{c|}{ Insured } & \multicolumn{3}{c|}{ Beneficiaries $^{*}$} \\
\hline Year & DI (\%) & CB (\%) & Total & DI (\%) & CB (\%) & Total & DI (\%) & CB (\%) & Total \\
& & & & & & & & & \\
\hline 1945 & 45 & 55 & 279,809 & 29 & 71 & $2,047,627$ & 25 & 75 & $5,913,280$ \\
\hline 1946 & 46 & 54 & 319,829 & 25 & 75 & $2,543,488$ & 25 & 75 & $7,698,059$ \\
\hline 1947 & 48 & 52 & 364,277 & 25 & 75 & $2,786,405$ & 25 & 75 & $8,319,959$ \\
\hline 1948 & 48 & 52 & 373,953 & 25 & 75 & $2,829,471$ & 25 & 75 & $8,546,451$ \\
\hline 1949 & 46 & 54 & 383,468 & 25 & 75 & $2,767,490$ & 25 & 75 & $8,377,863$ \\
\hline 1950 & 46 & 54 & 367,674 & 22 & 78 & $3,064,641$ & 25 & 75 & $8,200,636$ \\
\hline 1951 & 47 & 53 & 369,015 & 23 & 77 & $3,145,194$ & 25 & 75 & $8,402,295$ \\
\hline 1952 & 49 & 51 & 379,037 & 24 & 76 & $3,297,287$ & 27 & 73 & $8,766,544$ \\
\hline 1953 & 52 & 48 & 399,365 & 26 & 74 & $3,482,947$ & 28 & 72 & $4,945,032$ \\
\hline 1954 & 60 & 40 & 408,516 & 33 & 67 & $3,705,553$ & 36 & 64 & $5,480,900$ \\
\hline 1955 & 63 & 37 & 422,499 & 36 & 64 & $3,885,020$ & 39 & 61 & $5,688,470$ \\
\hline 1956 & 63 & 37 & 432,877 & 37 & 63 & $4,095,319$ & 40 & 60 & $5,943,787$ \\
\hline 1957 & 63 & 37 & 450,453 & 36 & 64 & $4,212,200$ & 39 & 61 & $6,193,669$ \\
\hline 1958 & 64 & 36 & 473,738 & 37 & 63 & $4,354,622$ & 39 & 61 & $6,608,933$ \\
\hline 1959 & 65 & 35 & 498,648 & 38 & 62 & $4,398,820$ & 41 & 59 & $6,980,454$ \\
\hline
\end{tabular}




\begin{tabular}{|l|l|l|l|l|l|l|l|l|l|}
\hline 1960 & 64 & 36 & 484,145 & 38 & 62 & $4,363,004$ & 41 & 59 & $7,180,261$ \\
\hline 1961 & 62 & 38 & 403,689 & 38 & 62 & $4,275,850$ & 41 & 59 & $6,895,821$ \\
\hline 1962 & 62 & 38 & 407,616 & 40 & 60 & $4,488,868$ & 43 & 57 & $7,189,276$ \\
\hline
\end{tabular}

Note: Data for 31 December of each year.

${ }^{*}$ Excluding insured.

CB: Collaborating Bodies.

DI: Direct Insurance.

Source: Anuarios Estadísticos de España 1950, 1955, 1960, 1963; Boletín Información del INP 1944-45; Revista española de Seguridad Social 1947-51; INP 1961, Memoria 1961; Estudio Estadístico del Seguro de Enfermedad 1954-57, drawn up by Alberto Rull Sabaté 1959, INGESA Archive Manuscript.

Table 4. Premiums collected and provisions for Sickness Insurance 1945-1952 (in current pesetas)

\begin{tabular}{|c|c|c|c|c|c|c|}
\hline & \multicolumn{3}{|c|}{ Premiums collected for Sickness Insurance } & \multicolumn{3}{c|}{ Compulsory sickness insurance provisions } \\
\hline Year & $\begin{array}{c}\text { National } \\
\text { Fund (\%) }\end{array}$ & $\begin{array}{c}\text { Collaborating } \\
\text { Bodies (\%) }\end{array}$ & Total & $\begin{array}{c}\text { Direct } \\
\text { Insurance (\%) }\end{array}$ & $\begin{array}{c}\text { Collaborating } \\
\text { bodies (\%) }\end{array}$ & Total \\
\hline 1945 & 28.74 & 71.25 & $284,706,228$ & 25.52 & 74.47 & $198,687,184$ \\
\hline 1946 & 24.96 & 75.03 & $427,581,733$ & 25.67 & 74.32 & $344,748,154$ \\
\hline 1947 & 25.11 & 74.88 & $643,500,339$ & 25.90 & 74.09 & $535,374,038$ \\
\hline 1948 & 25.41 & 74.58 & $882,989,416$ & 25.48 & 74.51 & $701,484,331$ \\
\hline 1949 & 25.43 & 74.56 & $1,054,656,995$ & 22.32 & 77.67 & $955,949,855$ \\
\hline 1950 & 22.14 & 77.85 & $1,489,355,694$ & 22.72 & 77.27 & $1,381,823,393$ \\
\hline 1951 & 22.65 & 77.34 & $1,701,447,965$ & 24.02 & 75.97 & $1,522,450,606$ \\
\hline 1952 & 24.07 & 75.92 & $2,264,712,108$ & 25.52 & 74.47 & $198,687,184$ \\
\hline
\end{tabular}

Source: Revista Iberoamericana de Seguridad Social (RISS), 1954, 3, 441.

Table 5. Direct insurance provisions (total in current pesetas)

\begin{tabular}{|c|c|c|c|c|c|}
\hline Year & $\begin{array}{c}\text { Economic } \\
\%\end{array}$ & $\begin{array}{c}\text { Medical } \\
\%\end{array}$ & $\begin{array}{c}\text { Pharmaceutical } \\
\%\end{array}$ & $\begin{array}{c}\text { Hospital } \\
\%\end{array}$ & Total \\
\hline 1946 & 10.03 & 51.75 & 35.27 & 2.92 & $50,714,106$ \\
\hline 1947 & 15.50 & 41.03 & 38.42 & 5.03 & $88,506,497$ \\
\hline 1948 & 17.29 & 41.71 & 35.19 & 5.79 & $138,705,290$ \\
\hline 1949 & 18.44 & 40.01 & 36.78 & 4.75 & $178,760,208$ \\
\hline 1950 & 15.22 & 38.88 & 41.07 & 4.80 & $213,384,023$ \\
\hline 1951 & 12.34 & 32.62 & 50.94 & 4.08 & $313,971,258$ \\
\hline 1952 & 12.72 & 34.67 & 48.72 & 3.87 & $365,794,798$ \\
\hline
\end{tabular}

Source: RISS, 1954, 3, 441. 
Table 6. Provisions by collaborating bodies (total in current pesetas)

\begin{tabular}{|c|c|c|c|c|c|}
\hline Year & $\begin{array}{c}\text { Economic } \\
\%\end{array}$ & $\begin{array}{c}\text { Medical } \\
\%\end{array}$ & $\begin{array}{c}\text { Pharmaceutical } \\
\%\end{array}$ & $\begin{array}{c}\text { Hospital } \\
\%\end{array}$ & Total \\
\hline 1946 & 10.32 & 52.91 & 36.13 & 0.62 & $147,973,078$ \\
\hline 1947 & 16.28 & 42.33 & 39.89 & 1.49 & $256,241,657$ \\
\hline 1948 & 17.55 & 43.10 & 36.18 & 3.15 & $396,668,748$ \\
\hline 1949 & 18.55 & 40.27 & 36.72 & 4.44 & $522,724,123$ \\
\hline 1950 & 16.01 & 39.20 & 41.45 & 3.33 & $742,565,832$ \\
\hline 1951 & 12.30 & 32.57 & 51.02 & 4.10 & $1,067,852,135$ \\
\hline 1952 & 12.77 & 34.63 & 48.70 & 3.89 & $1,156,655,808$ \\
\hline
\end{tabular}

Source: RISS, 1954, 3, 441.

Table 7. Health Care Facilities Plan 1954-1959.

\begin{tabular}{|c|c|c|c|c|c|c|c|c|}
\hline Year & $\begin{array}{c}\text { No. hospital } \\
\text { beds under } \\
\text { plan }\end{array}$ & $\begin{array}{c}\text { No. } \\
\text { Provisional } \\
\text { hospital beds }\end{array}$ & $\begin{array}{c}\text { No. hospital } \\
\text { stays under } \\
\text { plan }\end{array}$ & $\begin{array}{c}\text { No. } \\
\text { provisional } \\
\text { hospital stays }\end{array}$ & (A) & (B) & (C) & (D) \\
\hline 1954 & 2,619 & 733 & 364,175 & 208,104 & 102.95 & 81.20 & 458,476 & 6.47 \\
\hline 1955 & 5,713 & 617 & 646,054 & 190,176 & 115.74 & 94.73 & 917,351 & 6.50 \\
\hline 1956 & 8,144 & 609 & $1,122,347$ & 153,905 & 139.33 & 109.91 & $1,631,185$ & 7.66 \\
\hline 1957 & 8,952 & 446 & $1,306,248$ & 135,575 & 172.85 & 133.91 & $1,979,972$ & 8.96 \\
\hline 1958 & 8,952 & 453 & $1,625,518$ & 140,882 & 184.86 & 151.24 & $2,277,498$ & 8.87 \\
\hline
\end{tabular}

(A): Average cost of hospital stay under plan (in current pesetas).

(B): Average cost of stay in provisional hospital (in current pesetas).

(C): Average number of insured in hospitals under plan.

(D): Rate of hospitalisation per insured and month.

Source: Análisis funcional y resultados económicos de las instituciones sanitarias. Fiscal year 1958. INP. Document 45.

Table 8. Sickness Insurance. Income and Expenditure. Direct Insurance INP. 1954-1957 (in current pesetas)

\begin{tabular}{|l|r|r|r|r|}
\hline & \multicolumn{1}{|c|}{1954} & \multicolumn{1}{c|}{1955} & \multicolumn{1}{c|}{1956} & \multicolumn{1}{c|}{1957} \\
\hline Income & & & & \\
\hline Premiums & $633,920,341$ & $758,999,406$ & $508,928,686$ & $1,238,798,946$ \\
\hline State Contributions & $21,834,761$ & $27,577,841$ & $390,808,142$ & $32,393,137$ \\
\hline Contributions other Social Insurances & - & - & $220,372,331$ & $64,282,631$ \\
\hline Yields and interest & 307,053 & 894198 & 562,041 & 85,538 \\
\hline Other revenue & - & $1,322,072$ & - & - \\
\hline From collaborating bodies & $26,744,782$ & $4,861,532$ & - & $1,815,510$ \\
\hline Total Income & $682,806,937$ & $793,655,049$ & $1,120,671,200$ & $1,337,375,762$ \\
\hline Expenditure & & & & \\
\hline Benefits & $603,029,146$ & $745,234,342$ & $856,948,007$ & $1,118,001,095$ \\
\hline Administration Costs & $66,432,234$ & $76,553,408$ & $87,089,811$ & $123,758,368$ \\
\hline
\end{tabular}




\begin{tabular}{|l|r|r|r|r|}
\hline Other expenses & $5,266,523$ & $5,044,993$ & $5,020,110$ & $5,019,733$ \\
\hline To National Health Care Facilities Plan & $18,976,774$ & $22,712,203$ & $24,090,274$ & 992,197 \\
\hline Sinking Fund & $15,704,446$ & $18,817,303$ & $19,965,695$ & 717,296 \\
\hline To common insurance expenses & $709,409,123$ & $868,362,249$ & $993,113,897$ & $1,248,488,689$ \\
\hline Total transfers & $-26,602,186$ & $-74,707,200$ & $127,557,303$ & $88,887,073$ \\
\hline Difference
\end{tabular}

Source: Estudio Estadístico del seguro de Enfermedad, 1954, 1955, 1956 and 1957.

Table 9. Sickness Insurance. Income and Expenditure. Collaborating Bodies, 19541957 (in current peseta)

\begin{tabular}{|l|r|r|r|r|}
\hline & \multicolumn{1}{|c|}{1954} & \multicolumn{1}{c|}{1955} & \multicolumn{1}{c|}{1956} & \multicolumn{1}{c|}{1957} \\
\hline Income & & & & \\
\hline Premiums & $1,789,065,396$ & $1,832,515,294$ & $1,173,969,397$ & $2,959,416,521$ \\
\hline State Contributions & $18,544,839$ & $12,801,759$ & $901,606,846$ & $12,850,386$ \\
\hline Yields and interest & $2,459,413$ & $2,125,408$ & $3,011,206$ & $5,793,353$ \\
\hline Other revenue & - & - & - & $7,632,649$ \\
\hline Total Income & $1,810,069,648$ & $1,847,442,461$ & $2,078,587,449$ & $2,985,692,909$ \\
\hline Expenditure & & & & \\
\hline Benefits & $1,403,015,962$ & $1,506,090,528$ & $1,631,124,787$ & $2,296,337,758$ \\
\hline Administration Costs & $226,694,167$ & $217,618,915$ & $242,352,247$ & $345,830,513$ \\
\hline To INP Direct Insurance & $26,744,782$ & $4,861,532$ & & - \\
\hline To National Health Care & & & & $1,815,510$ \\
Facilities Plan Sinking Fund & $53,235,447$ & $50,462,535$ & $59,523,865$ & $22,369,524$ \\
\hline To common insurance expenses & $44,487,666$ & $43,243,004$ & $51,791,401$ & $6,544,617$ \\
\hline Total transfers & $1,754,178,024$ & $1,822,276,514$ & $1,984,792,300$ & $2,672,897,922$ \\
\hline Difference & $55,891,624$ & $25,165,947$ & $93,795,149$ & $312,794,987$ \\
\hline
\end{tabular}

Source: Estudio Estadístico del Seguro de Enfermedad, 1954, 1955, 1956 and 1957. 